\title{
The Sino-African Higher Education and Cultural Exchange before 1911: A Historical Review
}

\author{
Bouchaib Chkaif \\ Department of education, Zhejiang University, Wensan Road 181, Hangzhou, China \\ E-mail: bouchaib@zju.edu.cn
}

\begin{abstract}
In the last few decades, much ink has been spilt on the Sino-African relations. However, most literature concentrated on the economic, diplomatic, and political aspects of the Sino-African encounter, while few pieces of research touched upon the educational and cultural aspects of this encounter. With the increasing higher education and cultural exchange between China and the African countries in recent years, looking back at history, as a source of valuable insights to understand the present and forecast the future of this relationship, comes to the fore. This paper intends, through an analogical approach, to review and unveil the Sino-African higher education and cultural exchange before 1911. The author argues that by reviewing the educational and cultural impact of both sides' scholars' and travellers' visits with their backgrounds and legacies according to the modern literature on higher education exchange goals, these scholars' and travellers' visits would be regarded as the earliest forms of the Sino-African higher education and cultural exchange.
\end{abstract}

Keywords: China, Africa, higher education exchange, cultural exchange, knowledge transfer

DOI: $10.7176 / \mathrm{JEP} / 11-27-01$

Publication date:September $30^{\text {th }} 2020$

\section{Introduction}

Modern literature places mutual cultural understanding and knowledge transfer among the core objectives of higher education generally and higher education exchange, particularly (Atalar, 2020; Marilyn DeLong et al., 2011; Sowa, 2002; Vande Berg, Paige, \& Lou, 2012). However, these two goals are no new to the academia of ancient times. We can think analogically of education and higher education exchange in the context of Sino-African relations by investigating the ancient manifestations of higher education exchange goals, as set by modern academia, to trace the earliest forms of Sino-African higher education and cultural exchange in antiquity. This paper intends to unveil the Sino-African educational and cultural exchange before 1911 by focusing on both sides' scholars' and travellers' visits, their backgrounds, legacies, and impact. However, for clarity purposes, defining some key issues is due.

Firstly, in this paper, Africa is seen as a geographical unit. Thus, Africans are those who were born on the African continent, regardless of their ethnicity, skin colour, or religion. While China (as developed through centuries) is considered as a political unit. Thus, the term "Chinese" refers to those who were under the ambit of the Chinese imperial court. Besides, knowledge transfer and knowledge flow are used interchangeably.

Secondly, concerning with the research method, the author explores, through an analogical approach, the manifestation of higher education exchange goals as stated by modern academia in the Sino-African encounter of ancient times. This paper starts by demonstrating the modern criterion and ancient reality of education and higher education exchange in China and Africa (part one) before exploring the Chinese and African scholars' and travellers' visits as pioneers of the Sino-African education and cultural exchange (part two) and finally showing their legacies and impact in terms of educational, cultural and knowledge exchange (part three) before concluding how these scholars and travellers demonstrate the earliest forms of Sino-African higher education exchange (part four).

\section{Higher education exchange purposes: between modern criterion and ancient reality.}

Although education and higher education differs thematically and systematically between modern days and ancient times, their goals remained relatively instant as a channel and a vehicle to enhance mutual cultural understanding through exchange and facilitate knowledge flow.

\subsection{Higher education exchange goals: modern criteria}

In her paper, (Sowa, 2002) explained the importance of higher education exchange programs stating cultural understanding and knowledge transfer between nations among the core missions of student exchange programs. In the same context, (Vande Berg et al., 2012) believe that Cultural exchange and intercultural competence development are among the bosom aims of educational exchange programs, while (Marilyn DeLong et al., 2011) showed through an evaluation approach that building cultural awareness and cross-cultural experience are crucial components "to ensure professional survival in the $21^{\text {st }}$ century". Besides, higher education exchange is a crucial component of soft power(Johnstone \& Ji, 2018, p. 15; J. Li, 2018, p. 240; Zhou \& Spangler, 2018, p. 44) that 
depends on "the ability to attract and shape the preferences of others without the use of harsh power and coercion." (Joseph Nye, 2020; Nye, 2013). It is, in other words, another aspect of "public policy" and/or "social policy" (CHEPURINA, 2014).

Concerning Knowledge transfer, higher education, and higher education exchange is a double way mechanism for knowledge flow. It is a vehicle for knowledge transfer not only between generations but also between nations. The flow of individuals is usually accompanied by the flow of knowledge and cultural interactions between those individuals on a micro-level and their respective countries and nations on a macro-level.

In short, according to modern literature criteria, mutual cultural understandings and knowledge transfer are among the highest purposes of higher education exchange. However, was it possible for these objectives to be achieved in ancient times under the ancient reality of education?

\subsection{Education and higher education exchange: ancient reality in China and Africa}

It is widely believed that education in ancient times, if limited to formal education, was a privilege of the elite(Bodel \& Dimitrova, 2014, p. 119; Dutch, 2005, p. 254; Rock, 2012, p. 121). Literacy and access to knowledge through means such as writing was a tool for preserving social order (Lockard (2007, p. 113), unification(Fasold \& Connor-Linton, 2014, p. 441), and enforcing political dominance(Gaur, 2000).

To illustrate, education in ancient China generally remained inaccessible to the vast majority of the population despite the meritocratic public education system it had established during the imperial era(Biot, 1845). The "education for all" remained a dream that could only be possible to be realised after the founding of the new China in 1949(Yuan zhenguo, 2019) While in Africa, the majority of groups before the colonial era had a tradition of oral transmission of knowledge between generations(Shoko Yamada, 2019). The lack of formal and institutional education among the majority of African societies resulted not only in the loss of many of the African indigenous knowledge but also in the limited access and availability of education.

In short, education in both China and Africa was primarily limited to members of certain social classes, and the opportunities of higher education or higher education exchange under these circumstances were consequently scarce. Nevertheless, did this reality hinder the Chinese and the Africans from exchanging knowledge and interacting culturally with each other?

\section{Sino-African higher education exchange: scholars' travels and officials' visits.}

Despite being separated by thousands of miles of ocean, and the scarce opportunities to education and education exchange, there were outliers from both sides who followed a different path, surmounted all the difficulties, and strove to the seeking of knowledge and travel. They demonstrated the real meaning of the old saying, "reading ten thousand books and travelling ten thousand miles."1

\subsection{The Chinese scholars and travellers encounter with Africa}

The Sino-African relations date back as early as the Han dynasty(Anshan, 2005; Duggan, 2019; Duyvendak, 1949; Filesi, 1962; Hongwu, 2008; Jinyuan, 1984; Snow, 1988). It is believed that the Han and the Aksumite Kingdom Adulis diplomatic relations might be the earliest Sino-African relation (Shen fuwei, 1984b) which will later flourish under the silk road(zhang ying, 2014).

However, amid the $7^{\text {th }}$ Century, Both the Muslim and the Chinese empires reached their peak of glory and were looking to expand their borders, especially in central Asia, which was consisted of small warring states. The clash between the two powers was inevitable(Szczepanski, 2008), and the conditions for a confrontation were ripe(Olimat, 2015, p. 10).In July 751 BC, the Tang's armies under the command of Gao xianzhi and the Abbasside's (Tashi or Dashi as called by the Chinese) armies under the command of Abu Muslim Ziyad ibn Salih met in the banks of the Talas river(Bennett, 2016, p. 25; Jacques Gernet, JACQUES AUTOR GERNET, Nick Anchen, Professor Jacques Gernet, Norman Clifford, John Ulm, 1996, p. 259). After several days of fighting, the Chinese were defeated, and several Chinese soldiers were captured and brought to Baghdad(Africa Profile Writing Group, 1981, p. 326).

Regardless of the geopolitical consequences of the said battle, it was a turning point in terms of the knowledge and cultural exchange between China and the rest of the world, particularly northern Africa, as part of the Abbasids caliphate. The literate captives were asked to teach their knowledge and skills to Muslims in exchange for their freedom. Consequently, paper manufacturing, which was kept secret in China for centuries(Hunter, 1978, p. 33), was finally able to make its way to the heart of the Islamic caliphate and from then to Europe, Africa, and the rest of the world.

Among those captives was a young soldier called Du Huan, who will spend eleven years of his life in the Islamic caliphate before coming back to Guangzhou by the sea road. During his stay in the Abbasid caliphate, Du Huan will visit many places of the Islamic caliphate, including a place he called "Molin."

\footnotetext{
${ }^{1}$ In Chinese “读万卷书，走万里路” “du wan juan shu, zou wan li lu” see: (Zhao, p. 64)
} 
Regardless of where exactly this place is; the Moor or (Mauritania or Libya) (Bretschneider, 1871, p. 25), Morocco(Zhang xing, 1977, p. 567), Mali(Wang ting, 2001), Mandi (Africa Profile Writing Group, 1981, p. 326), Muqurra or Makuria (Smidt, 2001), Aksum(he fang chuan, 1985; Shen fuwei, 1980), Malindi(Duyvendak, 1949, p. 15; Laufer, 1919, p. 389; J. Needham, Gwei-Djen, \& Wang, 1971, p. 495). Historians and scholars assume, based on the few thousand characters left from his lost jingxingji in his relative $D u$ you's encyclopaedia "tongdian"(Du you, 1988) and other historical records ${ }^{1}$, that it should be somewhere in Africa, most likely in the western coast of the red sea(Hirth, 1885, pp. 204-205, 1909). Thus, it is believed that Du Huan might be the first Chinese to have ever set foot on Africa(Anshan, 2005; Li Anshan, 2009; Xu Yongzhang, 1980).

More than five centuries later, thanks to the Mongol monopoly and dominance over central Asia, the silk road become secure once again. Consequently, trade, embassies, scholars' movements, and cultural exchange between China and the west would flourish and prosper more than ever before(Shen fuwei, 1983, 1984a). In the first half of the $13^{\text {th }}$ century, another Chinese trader and explorer called wang dayuan would be the first Chinese to write about Southeast Asia(National Library Board Singapore.) and to reach the shores of today's Tanzania and Morocco (Tangier ${ }^{2}$ ) between 1334 to 1339 (Shen fuwei, 1983). This great explorer has sealed all his known world oceans and seas (Shen fuwei, 1984a). After his first expedition ended in 1332, he wrote the first draft of his travel records entitled "Dao yi Zhi" which he will later change its title to "Dao Yi Zhi Lue" or "A Brief Account of the Barbarians' Islands" (Rossabi, 2013, p. 51) then incorporate it into "Qing yuan xuzhi," which translates to "A Continuation of the History and Topography of Quanzhou," upon invitation by its author Wujian(Rockhill, 1915).

Even though the yuan dynasty did not last long, The Ming (1368-1644) first generation of emperors would encourage navigation and contact with foreign people. Consequently, the Chinese navy power reached its peak between (1405-1433) with the Muslim admiral Zheng He expeditions in the south seas (R. J. Ferguson \& Dellios, 2017, p. 109; Morris, 2013, p. 207; Tan, 2014, p. 476).

The background and motivation behind the Muslim admiral Zhenghe expeditions are still debatable between being peaceful voyages of showing goodwill(Aggarwal \& Newland, 2014, p. 60; Hoon, 2012, p. 68; Kerski, 2016, p. 360; Mahfud, 2012a, 2012b; Po, 2018, p. 74; Suryadinata, 2005, p. 52; Takács \& Cline, 2015, p. 552), power projection, and show of strength to shock and awe other nations(Callahan, 2009, p. 20; Fagan, 2012, p. 158; Geoff Wade, 2020; Reddick, 2014) in order to bring them within the ambit of the Ming tributary system(Dreyer \& Stearns, 2007; Graff \& Dreyer, 2007) or even a colonialist and expansion intentions(Tan Ta Sen, 2005; Wade, 2005). Nevertheless, these expeditions, known in the Chinese literature as "Zheng He Xia xiyang," without a doubt, have opened a new phase of the Chinese interaction with the outside world, including Africa. They become a symbol of Chinese pride for their diplomatic, political, and cultural significance.

Zheng He's crew consisted of a large number of ships and various personnel of whom were technicians, translators, diplomats, eunuchs, traders, officials, and military soldiers ${ }^{3}$. Those men would interact with the indigenous people of the places they visited peacefully in principal with some exceptional clashes ${ }^{4}$. The most important expeditions to our subject matter are the fifth (1417), sixth (1421), and the seventh (1431) expeditions when Zhenghe fleet reached the farthest points in the Indian ocean and landing on the coast of East Africa at Mogadishu, Malindi, Mombasa, and Zanzibar.

The Africans cheerfully welcomed the Chinese visitors and sent animals, spices, clothes, and jewellery as gifts with them to the emperor Yongle(Christina J. Moose, 2005, p. 100; Yamashita, Guadalupi, \& Bibb, 2006, p. 42). Besides, the ruler of Mogadishu did not only sent gifts but also sent an embassy to the Chinese emperor who received them with a warm welcome (Rossabi, 2014). Unfortunately, the great Chinese Muslim explorer will pass away during his seventh expedition in Calicut, and with him, the Chinese expeditions will come to an end(Tellis \& Rosenzweig, 2018, p. 123). Though, the Chinese African interaction will continue even with the European upper hand in the high seas.

During the Qing dynasty, when China retreated from the high seas to its isolationism(Cartwright, 2019) due to both internal and external factors, the Chinese interactions with the outside world would become less frequent and even banned. However, at the twilight of the Qing dynasty, some Chinese explorers will reach deep to the heart of Africa. In 1707 a Chinese Christian called Fan Shouyi or Luigi Fan (as known after being baptised) would reach today's South Africa in the course of his Christian missionary. In his travel memoirs (shen Jian lu), Luigi will describe South Africa and its people as well as the Christian missionary work of introducing Christianity to its people. Another Chinese explorer called Xie Qinggao (1765-1821), who, after 14 years of sea travels with the Portuguese, would return home to Macao in 1796 and write the "Hailu" with the help of the Guangdong scholar

\footnotetext{
${ }^{1}$ Such as: (Duan chengshi, 2012; Ouyangxiu, 1936; Zhao rukuo \& Yang bowen, 2000; zhou qu fei, 1936)

2 The home city of the famous Moroccan traveller who will also reach Wang dayuan home city Qinzhou in the second half of the $13^{\text {th }}$ century.

${ }^{3}$ The exact number of ships and personnel accompanied Zheng he in his seven voyages is also still unsettled between historian and scholars with estimations between 10000 to 40000 men and 100 to 300 ships. For more See: (Brezina, 2017, p. 46; N. Ferguson, 2011, p. 29; Hansen \& Curtis, 2014, p. 422; Jenkins, 1996, p. 6; Levathes, 1994, p. 82)

${ }^{4}$ Although those voyages were generally peaceful for commercial and diplomatic purposes, there has been instances where Zheng he's fleet, based on emperor Yongle instructions, used harsh power against those who were non-cooperative and hostile to the Chinese. See: (McKay et al., 2012, p. 573) (Aggarwal \& Newland, 2014, p. 71; Zhang, 2002)
} 
Yang bingnan(Zhang Wenqin). In this book, Xie would visit Mauritius and many other African coastal cities, which were part of the Portuguese empire and describe its people, their culture, and customs(A. Li, 2012, p. 51). Furthermore, following the Europeans, another Chinese would, for the first time, describe the interior part of Africa. "San Zhou youji," a book believed to be written by a Chinese called Ding lian who visited the inner parts of the African continent as part of a Dane mission in 1877, contain valuable information about the political, economic, and cultural situation of places such as Tanzania and Uganda(Ai zhouchang, 1989).

More and over, the Muslim community in China would also revive the link with the middle east and north Africa through the Muslim scholars such as Ma Dexin (or Ma fuchu) and Wang haoran, who would arrive in Cairo and study in Al-Azhar University in 1836 and 1905 respectively (George K. Harris., 1934; Ma, Ma, \& Na, 1988a; qian, 2018). Not to mention the thousands of Chinese workers who have been brought to Africa by the European settlers in the $18^{\text {th }}, 19^{\text {th }}$, and $20^{\text {th }}$ centuries to their mines and farms as foreign labourers would be the seeds of the Chinese diaspora in Africa today (A. Li, 2012, p. 62).

To summarise, those are the Chinese scholars and travellers who, historically, represents the direct contact with Africa during the last 2000 years of the imperial era. Their legacies and journeys are the basic foundation of the African-Chinese friendship today. However, the Africans could not miss the opportunity to visit the homeland of their Chinese peers. Africa is also home to great travellers, traders, scholars, and explorers who will reach as far as China and beyond.

\subsection{African scholars and travellers in the middle kingdom.}

Africans have a long history of travel and adventure. In the context of the Chinese African educational and cultural encounter in antiquity, there were several pioneers whose wonder and seeking of knowledge would lead them to the middle kingdom

During the Abbasid caliphate, the trade roads flourished between the east and the west, including the Islamic west (the maghrib). The Muslims of north and east Africa benefited from the spread of Islam in Central Asia to the Sind (Modern Pakistan and parts of India) as well as the pilgrimage to Mecca to gain much knowledge about the trade routes of the far east(Luṭfi Bin Mīlād, 2017). However, due to the absence of a written African history, we can only rely on the Arab and Chinese or other third-party sources to uncover the Sino-African encounter. For instance, the Arab sources contain some hints about Africans (mainly North Africans) who have had visited China, while the Chinese sources contain some records about Africans came to China either as slaves or as traders.

In his book "Travels of al-Gharnati," Abu Hamid Muhammad al-Gharnati mentioned a man called "Abderrahim almaghribi" or, as he refers to himself as "asini" (meaning the Chinese). He claimed to have been to China and came back with stories that "made people reluctant to believe him due to their extraordinariness" (AlGharnātī \& Wahb, 2003, p. 129). Another well-known Moroccan scholar and trader called "Qiwám ad-Dín of Ceuta" who will travel to China(Ibn Dehyah AL- Kalbi, 2002, p. 6) and even permanently reside as a judge in "QunjanFu"1 .He will meet with his fellow citizen, the great traveller Ibn Battuta during his way back from northern China to India(Battúta, 2013, p. 219; Batuta, Beckingham, \& Gibb, 2010, pp. 899-900).

From Ibn Battuta's account, we can also know that Qiwám ad-Dín is of a well-known family of travellers, scholars, and traders. His mother's brother is Abu'1 Qasim of Murcia, who like many other Moroccans, practised trade between Morocco and India(Luṭ̂i Bin Mīlād, 2017), and his brother is also a well-known scholar and Jurist called Abu Muhammad al-Bushri, who will meet him in Sijilmassa during his journey to "Bilad Sudan" (the country of blacks) (Batuta et al., 2010, p. 946). Therefore, Qiwám ad-Dín of Ceuta might be the first Moroccan to come to China, as we know from Ibn Battuta's travels.

The Arab resources also tell about Ibn Battuta $(1304-1368 / 1369)^{2}$ himself as one of "the greatest travellers of all times"(Nehru, 2004, p. 752). He was not only a traveller but also a Jurist, which qualified him to become a judge in Delhi(Byrne, 2012, p. 182; DUNN, 2005, p. 199), the Maldives Islands(Muhammad Ibn-'Abdallāh IbnBațtūtạ, 1829, p. 179; Suood, 2014, p. 30), the city of $\mathrm{Gao}^{3}$, and finally, his home country Morocco(Warf, 2010, p. 1519). Besides, he was a beknown scholar from a well-educated family(Page \& Facts on File, 2001, p. 98) who studied abroad in the academic centres of his time like Egypt(Andrews, 2020), Damascus(Robbers, 2006, p. 443), and Mecca(Daniel B. Baker, 1993, p. 360), where he had access to the Elite (or Ulama) (Stewart, 2012, p. 82). Furthermore, he was an ambassador not only of the Sultan of India to the emperor of China(Battuta \& Lee, 2010, p. 151; C. F. Beckingham, 1983, p. 268; C. F. Beckingham, Gibb, Defrémery, Bivar, \& Sanguinetti, 1958, p. 767; Stein, 2017, p. 263; Wolfe, 1997, p. 51) but of the entire Islamic world or Dar el-Islam.

It is speculated that during Ibn Battuta's stay in India, he met with another scholar and traveller, who might have been to China before Ibn Battuta(Jackson, 1987), known as Sa'id of Mogadishu. He provided Ibn Battuta

\footnotetext{
${ }^{1}$ The city of Qunjanfu exact location is still debatable, though most scholars assume that it refers to the modern Hangzhou city.

${ }^{2}$ His full name is Shams al-Dīn Abū 'Abd Allāh Muhammad ibn 'Abd Allāh ibn Muhammad ibn Ibrāhìm ibn Muhammad ibn Ibrāhīm ibn Yūsuf al-Lawātī al-Tanji, born in a family of legal scholars, ibn Battuta studied law and in 1325 he came to mecca for pilgrimage afterword he will continue his journey to Iraq and Syria before he return to morocco. For more about his life see: (DUNN, 2012)

${ }^{3}$ According to Ibn Khaldun see: (Serrano, Viguera, Páez López, \& Cabeza Méndez, 2006, p. 125)
} 
with valuable information about the political situation in Yuan China. However, there is less known about this Somalian scholar and his travels, except that he was a well-educated man from Alhabashah (today's Ethiopia) who lived in Mecca for nearly 30 years(Sherwani \& Joshi, 1974, p. 7). Thus, Ibn Battuta's accounts not only tell us about the places he visited but also about the people he either travelled with or met during his long journey(muhamad saeid samdi).

The Chinese sources tell about Africans in China either as slaves or traders. For instance, Mole and Mohe (Kunlun) ${ }^{1}$ are two well-known African slaves in Chinese folklore. In contrast, a trader called Zengjiani was reported to be a wealthy African trader who met with the Chinese emperor.

For instance, Mole was portrayed as a hero and emotionally intelligent slave with supernatural physical abilities. He helped his master Cui to kidnap his lover from the harem of her master (a government official) in the famous "Kunlun $\mathrm{Nu}$ " romance written by Pei Xing (825-880) (Wilensky, 2002, p. 15).In contrast, Mohe was portrayed as a pitiful slave in "Taiping guanji" 464 Juan by Li fang. He received harsh treatment by his master Tao Xian who entertained himself by torturing Mohe, believing that Mohe has supernatural powers, such as being able to see and breathe underwater (Wilensky, 2002, p. 12). What is more, there are also stories of the around 500 strong black battalion bodyguards owned by Coxinga, a general of the late Ming dynasty who was able to clear victories against the Manchu invasion of south China(Clements, 2011, p. 161).

Notwithstanding, the Chinese perception about Africans is not always related to slavery; there are also examples of wealthy black Africans who have been able to meet with the highest authority in China (the emperor). For instance, Zhengjiani, a wealthy trader, was received by the emperor of the Song and obtained the honourable title of (the guardian of prosperity). He was even regarded as an ambassador of his country to China. Zhengjiani was one of the early free black Africans to reach China and be received by the Song imperial court(Abegunrin \& Abidde, 2016, p. 158).

To conclude, the African community was present in ancient China through means of trade, travel, or scholarship that indeed offered flexible channels to cultural and educational exchange. Their legacies have undoubtedly influenced generations of both Chinese and Africans.

\section{The educational and cultural exchange of the Sino-African encounters.}

The records of the Chinese and African travellers are a valuable historical resource and a window to our ancient past. Their impact goes beyond the historical dimensions to the educational and cultural ones.

\subsection{The impact of Chinese scholars and travellers}

Both Du Huan, Zhenghe, fan shouyi, Xie Qinggao, and Ding lian are designers of the African image in the Chinese imagination. For our subject matter, we could summarise this impact into two dimensions: Cultural and educational.

To begin with, based on Du Huan's descriptions, we can know about the customs, religion, geography, weather, and the political situation of Molin. The paragraph of which Molin was mentioned is a panoramic description of Africa in the seventh century. Africa was portrayed as culturally diversified and religiously tolerant. It accommodated three of the world's most famous religions at the same time: Islam, Christianity, and "Zoroastrianism." Du Huan also tells the most important behavioural treats of each religion's believers in terms of eating habits, social ethics, customs, as well as social relations. These descriptions would eventually be replicated, taught, and cited in a number of both Chinese and western publications and researches. Therefore, they have influenced our perception of the continent: its inhabitants, their religions, beliefs, customs, and cultures.

Those records reprinted from Du Huan by his relative Du you, are also the blueprint of his predecessors who will visit the continent some centuries later for commercial and diplomatic purposes. Without Du Huan's reports about the people of Molin, generations of Chinese would not know about the Africans until the $11^{\text {th }}$ and the $15^{\text {th }}$ century. Du Huan, in this context, could be considered as the first "student" or rather "foreign student" to learn about Africa and its people first-hand through his travels to Molin. in the same vein, he is the first "teacher" to teach or tell his countryman about Africa and the far west. On the other hand, Du Huan and his colleagues were a channel of knowledge transfer. Without this encounter, the paper, porcelain, iron, bronze, and silk manufacturing skills would not be available to the Muhammadan, whose influence spread on three folds of Africa (east, west and north). Du Huan, after all, is not an illiterate person. In addition to his military skills, he was also an elegant speaker and well-educated men descended from a family of well-educated high-ranking officials.

Two centuries later, Wang dayuan would also reach farther than Du Huan. His "Dao Yi Zhi Lue" is a geographical masterpiece of its kind. He tells a detailed description of over 200 countries (some of which are African coastal city-states) and their people in the south seas. Besides, his records would be used as a primary material for the later Chinese mapping industry that will flourish during the Ming dynasty. To compare, if $\mathrm{Du}$ Huan informed his compatriots about the customs of the people of Africa, Wang da yuan informed them about the shape and the surface of the continent. Consequently, the Chinese become more familiar with the eastern part of

\footnotetext{
${ }^{1}$ The Kunlun is a term correlated with black slaves, though it is still unknown when this correlation started. See: Wilensky, 2002.
} 
the African continent, which appears to be more accurate in their maps than that of the Europeans (Snow, 1988).

Although the records of Ma Huan and Fei Xin about the travels of Zhenghe were confiscated in the 1470s and destroyed(Boorstin, 1985, 1983, p. 268) by the ministry of war backed by the Confucian bureaucrats on the bases of being "deceitful exaggerations of bizarre things far removed from the testimony of people's eyes and ears"(Krieger, Jantzen, \& Neill, 1992, p. 289; Landes, 1999, p. 97; Levathes, 1994, p. 179; Joseph Needham \& Ronan, 1981-, p. 146; Pagden, 2007, p. 57), Zhenghe legacy managed to live in the collective memory of the Chinese and the African people. They were borrowed into literature through novels like "the Romance of the ThreeJeweled Eunuch descending upon the western sea" by Luo Maodeng in 1597(Wyatt, 2010, p. 121), the Ethiopian novelist Jakoub Adol Mar in his novel "Makeda ou la fabuleuse histoire de la reine Saba" ${ }^{1}$, Heather Terrell's 2005 novel "The Map Thief," Vernor Vinge's 1999 science-fiction novel "A Deepness in the Sky"2. Not to mention the special status Zhenghe occupies in China, especially after 2005, which marks 600 years from the beginning of his expeditions.

Concerning the Sino-African people to people exchange as one of higher education exchange purposes nowadays, Zhenghe has succeeded before 600 years in establishing permanent people to people ties through the people of his crew who settled in the places he visited. For instance, in Kenya, Chinese scientists run DNA tests for residents in the Kenyan Lamu Island to find out that some of them are of Chinese ancestors(Amos Kareithi, Sun, 2013; Rey, 2016; Rice, 2010). Among them, a 19 years old Kenyan named Mwamaka Sharifu, whose story would receive much attention in the early 2000s and would acquire a Chinese government scholarship to study medicine in China(China daily, 2005).

Zhenghe was also an educator; it is said that during his stay in Java, he introduced the Chinese system of governance and politics to its king and helped him restore order and control over his kingdom (Mahfud, 2012a). He also left behind members of his fleet in the places he visited. Those members would eventually transfer their knowledge and skills and share them with the indigenous people.

In short, the travels of Zhenghe are an official encounter between the Chinese and their African peers. They are a solid foundation of the Sino-African friendship and historical diplomatic ties. Zhenghe today is hailed by the Chinese as an envoy of peace and goodwill. He, indeed, has achieved remarkable results in terms of diplomatic, educational, and cultural exchange between China and Africa.

Despite the "close-door policy" followed by the late Ming emperors and endorsed by the Qing court, Chinese people never lost interest in overseas. Instead, it flourished under the European rule in China and Africa. For instance, a European mission would help Fan shouyi to contribute to the Christianization of Africa as a priest himself and part of the Italian missionary(Thierry Meynard, 2018). In his journey as a priest and the first Chinese to visit Europe, Fan would pass by south Africa and include accounts about it in his travel records "Shen Jian lu"(Jenny Huangfu Day, 2018). He was the late Qing window to the religious status of Africans under the European rule.

What is more, Xie Qinggao was one of the few Chinese who mastered the sea roads and was part of the Portuguese crew as a translator and guide. In the process, he learned many local languages and immersed himself into the local cultures and customs of the East African societies. After he lost his sight, he came back to Macao, where his stories will attract another Chinese literati or "Junren"3 called Yang bingnan, who will write them in the famous "Hailu. However, to this point, the Chinese knowledge of Africa was limited to the shores and costal parts. Not until Ding lian and his colleagues would travel to the interior of the African continent as part of a Dane mission and leave remarkable descriptions that would be included in the Chinese official and geographer Lin Zexu work "Xi Zhou Zhi."

Furthermore, the Chinese Muslim scholar and traveller Ma Dexin would write his travels Memoire "Chao Jin Tuji" upon his return to China in the second half of the $19^{\text {th }}$ century. Ma Dexin records provide descriptions of the middle east and northern Africa, particularly Egypt, where he studies Islamic studies and the Arabic language in the Egyptian Al-Azhar university in 1841 (Ma, Ma, \& Na, 1988b; Tie \& Li, 1994). In addition, between 1905 to 1907 another Muslim scholar called Wang haoran would arrive to Egypt for a short-term study after performing Hajj (Benite, 2008; John T. Chen, 2014).

Moreover, most of the official imperial historical records are extracted from or based on the writing of those who visited Africa such as "jingxingji" by Du Huan, "Dao Yi Zhi Lue" by wang da yuan, "xi yang fan Guo Zhi" by gong Zhen, "Xing cha sheng lan" by Fei Xin, "ying-yang sheng lan" by Ma Huan et cetera. Even the nonofficial historical books and encyclopaedias such as "yu yang za zu" by Duan cheng shi, "Zhu fan shi" by Zhao rukuo, "tongdian" by Du you, "ling wai Tai da" by Zhou Qu Fei, and others are mostly dependent on the records of the few Chinese who have visited Africa. Therefore, the comprehension of the Chinese about Africa and the

\footnotetext{
${ }^{1}$ He wrote: "a yellow prince from the country of miracle come from the ocean and asked the hand of the queen, but she rejected him - in spite of his marvelous wealth and power... And her "green fleet" reached as far as India, Malaysia, China, to buy great quantities of silk.". (Mar, 2001)

${ }^{2}$ In which he borrowed the name Geng he for one of his personalities in an indication to the great admiral Zhenghe.

3 "Junren" is an honorable title for those who passed the imperial examination (1644-1911).
} 
Africans came generally from these few resources written by scholars and travellers who interacted personally with the African continent and its people.

To sums up, the above-mentioned Chinese scholars and travellers were the first students and teachers to learn/teach about Africa and its people's culture, customs, and political status. They had successfully achieved today's higher education goals. Therefore, they are the early form of Sino-African educational and cultural exchange.

\subsection{The impact of African scholars and travellers.}

Similar to their Chinese peers, African scholars and travellers also reached the shores of the middle kingdom and left behind them a legacy that influenced generations' perspectives about China. From the Arab resources, we can find out scholars like Ibn Battuta, Qiwám ad-Dín of Ceuta, Abdurrahman almaghribi, and others as the trailblazers to have visited China for the seeking of adventure, travel, trade and/or scholarship.

Perhaps the most influential among them is the Moroccan scholar and traveller Ibn Battuta. His masterpiece "A Gift to Contemplators of the Wonders of Cities and the Marvels of Travelling" or just "Arihla," had an immense influence on the geographical exploration of the $15^{\text {th }}$ century. Ibn Battuta and his editor Ibn Juzayy following the order of the Sultan Abo Inan, brilliantly described the east and its people in a fascinating way that would make any reader eager to visit these places.

The request of the Sultan Abu Inan to Ibn Battuta to recite his travels to Ibn Juzayy and compile the "Arihla" is another form of knowledge transfer from ibn Battuta to his contemporary and successors alike. Besides, in his travels in Dar El-Islam or the Adobe of Islam, Ibn Battuta was sharing his professional knowledge as a judge. At the same time, he was also learning from the other Imams along his journey. In fact, Ibn Battuta's primary motives of travel, besides the pilgrimage, was to have access to the best scholars and libraries, which by then were in Cairo, Alexandria, and Damascus. He was, after all, "an international student" in today's terms, in all the places he visited during his 30 years-long journeys of travels.

Ibn Battuta's Odyssey(Waines, 2010) is an iconic piece of the "Arihla" literature. For instance, the stories he tells, even with less accuracy in terms of dates and places $^{1}$, are a unique historical material from a man who has been in the middle of events. Ibn Battuta, in the meantime, does not only tell about himself but also about the people he met, accompanied, or visited, such as the Moroccan scholar Qiwám Adin of Ceuta and his mother's brother Mohammed Albushri. We can also know about another scholar associated with ibn Battuta travels and is believed to have visited China before Ibn Battuta himself called "Said of Mogadishu". The same principle also applies to those African slaves such as Mohe, Mole, the 500 men strong battalions, or the wealthy trader Zengjiani who have left an indelible impression on the Chinese and their perception about Africa.

\section{Conclusion}

The Sino-African encounter in ancient times was not limited to one aspect versus others, but it was diversified in its entirety. The earliest forms of the Sino-African educational and cultural exchange could be traced back to those early "students and teachers" who set foot on Africa and the middle kingdom as travellers and traders. Their personnel backgrounds, intentions, and legacies, if judged by modern higher education exchange goals criteria, would be regarded as the ancient form of Sino-African higher education and cultural exchange. Du Huan, wang dayuan, Zhenghe, Fei Xin, Ma Huan, fan shouyi, Xie Qinggao, ding lian, and Ma Dexin could be considered the early Chinese "foreign student" to conduct research and write reports about Africa. The same applies to those Africans, such as Ibn Battuta, Qiwám Adin of Ceuta, Abderrahim almaghribi, Said of Mogadishu, Zengjiani et cetera, whose journeys led them to the middle kingdom where they will be a two-way channel of knowledge and cultural exchange between the Africans and the Chinese. The travel records of scholars from both sides would be the primary sources of generations' comprehension of each other. They have achieved the cultural and knowledge exchange as two of the main goals of higher education exchange today. Put it simply, if cultural and knowledge exchange is among higher education exchange purposes by modern criteria on the one hand and those goals are manifested and achieved by those scholars' and travellers' visits, on the other hand, their encounter shall be considered as the earliest forms of the Sino-African higher education exchange. However, little known about the Sino-African encounter before the Tang dynasty, the late Ming and the Qing dynasties. Besides, we still know but few about the Africans discovery of china instead of the Chinese discovery of Africa. Educational and cultural exchange between China and Africa during these periods, especially from the standpoint of Africans, is a valuable/needed and promising future research direction.

\section{References}

Abegunrin, O., \& Abidde, S. O. (2016). Pan-Africanism in modern times: Challenges, concerns, and constraints I edited by Olayiwola Abegunrin and Sabella Ogbobode Abidde. African governance and development.

\footnotetext{
${ }^{1}$ Perhaps because of the time difference between his travels and the writing of the "Arihla" which is as long as 10 years.
} 
Lanham, Maryland: Lexington Books.

Africa Profile Writing Group (1981). Fei zhou gaikuang. beijing: Shijie zhishi chubanshe.

Aggarwal, V. K., \& Newland, S. A. (2014). Responding to China's rise: US and EU strategies. The Political Economy of the Asia Pacific, 1866-6507: Vol. 15. Cham: Springer.

Ai zhouchang (1989). "San zhou youji" chuxi--dao dongfei neichen luyuo de di yi ge zhongguo ren de jishi [ A priliminary analysis of "Three continents travel records" — — A documentary of the first Chinese to travel to the interior of East Africa. Lishi Jiaoxue Wenti. (04), 58-61.

Al-Gharnāțī, A. H. M., \& Wahb, Q. M. (2003). Riḥlat al-Gharnāțī [Travels of Al-gharnati]: Tuhfat al-albāb wanukhbat al-i jāàb wa-riḥlat ilá Ūrubbah wa-Āsiyah / Abū Hāmid Muhammad al-Gharnāțī ; harrarahā waqaddama lahā Qāsim Wahab (880-03 al-Ṭab ah 1). 880-05 Irtiyād al-āfāq. 880-04 Abū Zaby: Dār al-Suwaydī lil-Nashr wa-al-Tawzī'; Bayrūt : al-Mu' assasah al- 'Arabīyah lil-Dirāsāt wa-al-Nashr.

Amos Kareithi (Sun, 2013, February 3). 600 years of Chinese bloodline in Lamu. The Standard Group PLC. Retrieved from https://www.standardmedia.co.ke/special-reports/article/2000076491/600-years-of-chinesebloodline-in-lamu

Andrews, E. (2020, July 22). Why Moroccan Scholar Ibn Battuta May Be the Greatest Explorer of all Time. Retrieved from https://www.history.com/news/why-arab-scholar-ibn-battuta-is-the-greatest-explorer-of-alltime

Anshan, L. (2005). African Studies in China in the Twentieth Century: A Historiographical Survey. African Studies Review, 48(1), 59-87. Retrieved from www.jstor.org/stable/20065045

Atalar, A. (2020). Student Exchange: The First Step Toward International Collaboration. In A. AI-Youbi, A. Zahed, \& W. G. Tierney (Eds.), Successful global collaborations in higher education institutions (pp. 63-71). Cham, Switzerland: Springer Open. https://doi.org/10.1007/978-3-030-25525-1_7

Battuta, I., \& Lee, S. (2010). The Travels of Ibn Battuta: In the Near East, Asia and Africa: Cosimo, Incorporated. Battúta, I. (2013). Travels in Asia and Africa, 1325-1354. The Broadway travellers: Vol. 18. London: Routledge.

Batuta, I., Beckingham, C. F., \& Gibb, H. A. R. (2010). The travels of Ibn Battuta, AD 1325-1354: Volume 4. Farnham, Surrey, Burlington, VT: Ashgate Pub. Retrieved from http://site.ebrary.com/lib/alltitles/docDetail.action?docID=10495682

Beckingham, C. F. (1983). Between Islam and Christendom: Travellers, facts and legends in the Middle Ages and the Renaissance. London: Variorum Reprints.

Beckingham, C. F., Gibb, H. A. R., Defrémery, C., Bivar, A. D. H., \& Sanguinetti, B. R. (1958). The Travels of Ibn Battuta, A.D. 1325-1354. Hakluyt Society Second Series: Published for the Hakluyt Society at the University Press.

Benite, Z. B.-D. (2008). " Nine years in Egypt": Al-Azhar University and the Arabization of Chinese Islam1. Hagar, 8(1), 1.

Bennett, M. (2016). The Hutchinson dictionary of ancient \& medieval warfare. Abingdon, Oxon: Routledge.

Biot, É. (1845). Essai sur l'histoire de l'instruction publique en Chine et de la corporation des lettrés.[ Essay on the History of Public Education in China and the Corporation of literates]: B. Duprat (Paris).

Bodel, J. P., \& Dimitrova, N. M. (Eds.) (2014). Brill studies in Greek and Roman epigraphy: Vol. 5. Ancient documents and their contexts: First North American Congress of Greek and Latin Epigraphy / edited by John Bodel and Nora Dimitrova. Leiden: Brill. Retrieved from http://search.ebscohost.com/login.aspx?direct=true\&scope $=$ site \&db=nlebk\&db=nlabk\&AN=919137

Boorstin, D. J. (1985, 1983). The discoverers. New York: Vintage Books.

Bretschneider, E. (1871). On the Knowledge Possessed by the Ancient Chinese of the Arabs and Arabian Colonies, and Other Western Countries, Mentioned in Chinese Books: Trübner \& Company. Retrieved from https://books.google.com/books?id=kZPMZ0AkLzoC

Brezina, C. (2017). Zheng He: China's greatest explorer, mariner, and navigator (First edition). Spotlight on explorers and colonization. New York: Rosen Publishing.

Byrne, J. P. (2012). Encyclopedia of the Black Death. Santa Barbara, Calif.: ABC-CLIO.

Callahan, W. A. (2009). China: The Pessoptimist Nation: OUP Oxford. Retrieved from https://books.google.com/books?id=8HxJFtQNeQUC

Cartwright, M. (2019, February 8). The Seven Voyages of Zheng He. Ancient History Encyclopedia. Retrieved from https://www.ancient.eu/article/1334/the-seven-voyages-of-zheng-he/

CHEPURINA, M. (2014). Higher education co-operation in the toolkit of Russia's public diplomacy. Rivista Di Studi Politici Internazionali, 81(1 (321)), 59-72. Retrieved from www.jstor.org/stable/43580583

China daily (2005, July 11). Is this young Kenyan Chinese descendant? Retrieved from http://www.chinadaily.com.cn/english/doc/2005-07/11/content 459090.htm

Christina J. Moose (Ed.) (2005). Great Events from History: The Renaissance \& early modern era, 1454-1600. United kingdom: Salem Press.

Clements, J. (2011). Coxinga and the Fall of the Ming Dynasty. New York: The History Press. Retrieved from 
http://gbv.eblib.com/patron/FullRecord.aspx?p=844849

Daniel B. Baker (1993). Explorers and discoverers of the world. Detroit, London: Gale Research.

Dreyer, E. L., \& Stearns, P. (2007). Zheng He: China and the oceans in the early Ming dynasty, 1405-1433 / Edward l. Dreyer. The library of world biography. New York, London: Pearson Longman.

$\mathrm{Du}$ you (1988). Tongdian [Comprehensive Institutions]. Beijing: Zhonghua shuju. Retrieved from https://ctext.org/tongdian/zhs?searchu=\%E6\%9D\%9C\%E7\%8E\%AF

Duan chengshi (2012). You yang Za zu [ The Miscellaneous Morsels from Youyang]. Shanghai: Shanghai guji chubanshe.

Duggan, N. (2019). Sino-African Relations Research. In N. Duggan (Ed.), Governing China in the 21st Century. Competition and Compromise among Chinese Actors in Africa: A Bureaucratic Politics Study of Chinese Foreign Policy Actors / Niall Duggan (pp.9-28). Singapore: Palgrave Macmillan. https://doi.org/10.1007/978-981-13-8813-2_2

DUNN, R. E. (2005). The adventures of Ibn Battuta, a Muslim traveler of the 14th century. Ross E. Dunn (Rev. ed. with new preface). Berkeley, Calif., London: University of California Press.

DUNN, R. E. (2012). Introduction. In A Muslim Traveler of the Fourteenth Century. The Adventures of Ibn Battuta (3rd ed., pp. 1-12). University of California Press. Retrieved from www.jstor.org/stable/10.1525/j.cttlpnht1.11

Dutch, R. S. (2005). The educated elite in 1 Corinthians: Education and community conflict in Graeco-Roman context / Robert S. Dutch. Journal for the study of the New Testament. Supplement series: Vol. 271. London, New York: T \& T Clark International.

Duyvendak, J.J.L. (1949). China's Discovery of Africa: Lectures Given at the University of London on January 22 and 23, 1947: A. Probsthain.

Fagan, B. M. (2012). Beyond the blue horizon: How the earliest mariners unlocked the secrets of the oceans / Brian Fagan. New York, NY: Bloomsbury Press.

Fasold, R. W., \& Connor-Linton, J. (2014). An Introduction to Language and Linguistics: Cambridge University Press. Retrieved from https://books.google.com/books?id=gpp7BAAAQBAJ

Ferguson, N. (2011). Civilization: The West and the rest (1st American ed.). New York: Penguin Press.

Ferguson, R. J., \& Dellios, R. (2017). The politics and philosophy of Chinese power: The timeless and the timely. Lanham: Lexington Books.

Filesi, T. (1962). China and Africa in the Middle Ages. Cass library of African studies, general studies: no.144. London: Cass for the Central Asian Research Centre.

Gaur, A. (2000). Literacy and the Politics of Writing: Intellect Books Limited. Retrieved from https://books.google.com/books?id=t7qrDwAAQBAJ

Geoff Wade (2020). Zheng He and Ming China's Voyages in the Early 15th Century. In Oxford Research Encyclopedia of Asian History. https://doi.org/10.1093/acrefore/9780190277727.013.235

George K. Harris. (1934). Al-azhar THROUGH CHINESE SPECTACLES. The Muslim World, 24(2), 178-182. https://doi.org/10.1111/j.1478-1913.1934.tb00293.x

Graff, D. A., \& Dreyer, E. L. (2007). The Journal of Military History, 71(1), 213-214. Retrieved from www.jstor.org/stable/4138042

Hansen, V., \& Curtis, K. R. (2014). Voyages in world history (Second edition). Boston MA: Wadsworth/Cengage Learning.

He fang chuan (1985). akesumu [Aksume]. Xi Ya Fei Zhou. (05), 56-62.

Hirth, F. (1885). China and the Roman Orient: Researches into their ancient and mediaeval relations as represented in old Chinese records. Germany: G. Hirth.

Hirth, F. (1909). Early Chinese Notices of East African Territories. Journal of the American Oriental Society, 30(1), 46-57. https://doi.org/10.2307/3087496

Hongwu, L. (2008). Sino-African Exchanges: The Importance of the History of Civilizations. Contemporary Chinese Thought, 40(1), 73-82. https://doi.org/10.2753/CSP1097-1467400106

Hoon, H. S. (2012). Zheng He's Art of Collaboration: ISEAS Pub. Retrieved from https://books.google.com/books?id=OeUEBAAAQBAJ

Hunter, D. (1978). Papermaking: The History and Technique of an Ancient Craft. Dover Books Explaining Science: Dover Publications. Retrieved from https://books.google.com/books?id=i6Cijf2BOZYC

Ibn Dehyah AL- Kalbi (2002). min 'alqam alhajar 'iidh kadab wafajar wa'asqat adalata man qal min alsahabah malaho 'ahjor [ I leave whoever casts the stone if he lies, debauch and Drop the justice of the companions]: Matbaat Fadala.

Jackson, P. (1987). The Journal of the Royal Asiatic Society of Great Britain and Ireland. (2), 324-325. Retrieved from www.jstor.org/stable/25212166

Jacques Gernet, JACQUES AUTOR GERNET, Nick Anchen, Professor Jacques Gernet, Norman Clifford, John Ulm (1996). A history of Chinese civilization (2nd ed.). Cambridge: Cambridge University Press.

Jenkins, E. (1996). Pan-African Chronology: A Comprehensive Reference to the Black Quest for Freedom in Africa, 
the Americas, Europe, and Asia. Pan-African Chronology Series: McFarland \& Company.

Jenny Huangfu Day (2018). Introduction. In Qing Travelers to the Far West: Diplomacy and the Information Order in Late Imperial China (pp. 1-29). Cambridge University Press. https://doi.org/10.1017/9781108571005.001

Jinyuan, G. (1984). China and Africa: The Development of Relations over Many Centuries. African Affairs, $83(331), 241-250$.

John T. Chen (2014). Re-Orientation: The Chinese Azharites between Umma and Third World, 1938-55. Comparative Studies of South Asia, Africa and the Middle East, 34(1), 24-51.

Johnstone, C. J., \& Ji, L.-L. (Eds.) (2018). Spotlight on china: Volume 5. The rise of China-US international cooperation in higher education: Views from the field. Leiden The Netherlands, Boston MA: Brill Sense.

Joseph Nye (2020, July 5). Soft Power and Higher Education. Retrieved from http://forum.mit.edu/articles/softpower-and-higher-education/

Kerski, J. J. (2016). Interpreting our world: 100 discoveries that revolutionized geography / Joseph J. Kerski. Santa Barbara, California: ABC-CLIO.

Krieger, L., Jantzen, S., \& Neill, K. (1992). World history: Perspectives on the past. Lexington, Mass.: D.C. Heath.

Landes, D. S. (1999). The wealth and poverty of nations: Why some are so rich and some so poor. New York: W.W. Norton \& Company.

Laufer, B. (1919). Sino-Iranica: Chinese Contributions to the History of Civilization in Ancient Iran, with Special Reference to the History of Cultivated Plants and Products. Anthropological Series - Field Museum of Natural History: Field Museum of Natural History. Retrieved from https://books.google.com/books?id=KgePrCOwqyIC

Levathes, L. (1994). When China ruled the seas: The treasure fleet of the Dragon Throne, 1405-1433. New York, London: Simon \& Schuster.

Li, A. (2012). A history of overseas Chinese in Africa to 1911. New York: Diasporic Africa Press.

Li, J. (2018). Conceptualizing soft power of higher education: Globalization and universities in China and the World / Jian Li. Perspectives on rethinking and reforming education. Singapore: Springer.

Li Anshan (2009). Zhongfei guanxi yanjiu sanshi nian gaikuang [ a Briefing of thirty years of sino-african relations research]. Xi Ya Feizhou. (4), 5-15.

Lockard, C. (2007). Societies, networks and transitions: A global history. Boston, Mass.: Houghton mifflin.

Luṭī Bin Mīlād (2017). almagharibat watijarat alhind min albahr al'ahmar 'iilaa almuhit alhindii walsiyn [ The Moroccans and the Indian trade from the red sea to the Indian ocean and china]. Annales Islamologiques. (51), 223-238. https://doi.org/10.4000/anisl.3884

Ma, D., Ma, A., \& Na, G. (1988a). Chao jin tu ji (Di 1 ban). Zhongguo Hui zu gu ji cong shu. Yinchuan Shi: Ningxia ren min chu ban she.

Ma, D., Ma, A., \& Na, G. (1988b). Chao jin tu ji (Di 1 ban). Zhongguo Hui zu gu ji cong shu. Yinchuan Shi: Ningxia ren min chu ban she.

Mahfud, C. (2012a). Lessons From Zheng He: Love of Peace and Multiculturalism. Zheng He \& the Afro-Asian World. Melaka: PERZIM and the International Zheng He Society in Singapore.

Mahfud, C. (2012b). Lessons From Zheng He: Love of Peace and Multiculturalism. Zheng He \& the Afro-Asian World. Melaka: PERZIM and the International Zheng He Society in Singapore.

Mar, J. A. (2001). Makéda ou la fabuleuse histoire de la reine de Saba[Makeda or the fabulous story of Queen Sheba]. Paris: M. Lafon.

Marilyn DeLong, KeySook Geum, Kelly Gage, Ellen McKinney, Katalin Medvedev, \& Juyeon Park (2011). Cultural exchange: Evaluating an alternative model in higher education. Journal of Studies in International Education, 15(1), 41-56. https://doi.org/10.1177/1028315309334619

McKay, J. P., Hill, B. D., Buckler, J., Crowston, C. H., Wiesner-Hanks, M. E., Ebrey, P. B., \& Beck, R. B. (2012). Understanding World Societies, Combined Volume: A Brief History: Bedford/St. Martin's.

Morris, I. (2013). The Measure of Civilization: How Social Development Decides the Fate of Nations. Princeton: Princeton University Press. Retrieved from http://www.jstor.org/stable/10.2307/j.ctt1r2fj0 https://doi.org/10.2307/j.ctt1r2fj0

Muhamad saeid samdi. maghariba ...dakhalu asiyn [ Moroccans ... have entered China]. In Wizārat al-Awqāf waal-Shu'ūn al-Dīnìyah (Ed.) 2006 (Vol. 15, pp. 339-340).

Muhammad Ibn-'Abdallāh Ibn-Battūța (1829). The Travels of Ibn Battuta: Oriental Translations Fund. Retrieved from https://books.google.com/books?id=IZ5CAAAAcAAJ

National Library Board Singapore. Wang Dayuan. Retrieved from https://eresources.nlb.gov.sg/history/events/61d49d33-d5cd-48fc-b91b-652ca64e87c4

Needham, J. [J.], Gwei-Djen, L., \& Wang, L. (1971). Science and Civilisation in China: Volume 4, Physics and Physical Technology, Part 3, Civil Engineering and Nautics: Cambridge University Press.

Needham, J. [Joseph], \& Ronan, C. A. (1981-). The shorter science and civilisation in China. Cambridge: Cambridge University Press. 
Nehru, J. (2004). Glimpses of world history: Being further letters to his daughter, written in prison, and containing a rambling account of history for young people. Haryana: Penguin Books.

Nye, J. S. (2013, April 29). What China and Russia Don't Get About Soft Power. Foreign Policy. Retrieved from https://foreignpolicy.com/2013/04/29/what-china-and-russia-dont-get-about-soft-power/

Olimat, M. (2015). China and Central Asia in the post-Soviet era: A bilateral approach / Muhamad S. Olimat. Lanham: Lexington Books.

Ouyangxiu (1936). Xintangshu [New Book of Tang]. Sibu bei yao: Shangwu yin shuguan.

Pagden, A. (2007). Peoples and Empires: A Short History of European Migration, Exploration, and Conquest, from Greece to the Present. Modern Library Chronicles Ser: v.Vol. 6. Westminster: Random House Publishing Group.

Page, W. F., \& Facts on File, I. (2001). Encyclopedia of African History and Culture: African kingdoms (500 to 1500). Encyclopedia of African History and Culture: Facts on File. Retrieved from https://books.google.com/books?id=gK1aAAAAYAAJ

Po, R. C. (2018). The blue frontier: Maritime vision and power in the Qing Empire / Ronald C. Po, London School of Economics and Political Science. Cambridge oceanic histories. Cambridge, United Kingdom, New York, NY: Cambridge University Press.

Qian, P. s. (2018). Ai ji jiu nian (Di 1 ban). Zhong wai guan xi shi dian zang cong shu. Beijing: Hua wen chu ban she.

Reddick, Z. (2014). The Zheng He Voyages Reconsidered: A Means of Imperial Power Projection. Quarterly Journal of Chinese Studies, 3(1), 55.

Rey, S. (2016, September 17). DNA test proves some East Africans are descendants of Chinese sailors shipwrecked on Kenya's shores 600 years ago. Sola Rey. Retrieved from http://solarey.net/dna-test-proves-east-africansdescendants-chinese-sailors-shipwrecked-kenyas-shores-600-years-ago/

Rice, X. (2010, July 25). Chinese archaeologists' African quest for sunken ship of Ming admiral. The Guardian. Retrieved from https://www.theguardian.com/world/2010/jul/25/kenya-china

Robbers, G. (2006). Encyclopedia of World Geography: Three-volume Set. New York: Infobase Pub.

Rock, W. J. (2012). The Pursuit Of Liberal Education: Xlibris US.

Rockhill, W. W. (1915). Notes on the Relations and Trade of China with the Eastern Archipelago and the Coast of the Indian Ocean during the Fourteenth Century. Part II. T'oung Pao, 16(1), 61-159.

Rossabi, M. (Ed.) (2013). Nalanda-Sriwijaya series. Eurasian influences on Yuan China. Singapore: ISEAS. Retrieved from http://www.cambridge.org/core/product/identifier/9789814459730/type/BOOK

Rossabi, M. (2014). A history of China. The Blackwell history of the world. Chichester West Sussex England, Malden MA: Wiley Blackwell.

Serrano, A., Viguera, M. J., Páez López, J., \& Cabeza Méndez, J. M. (2006). Ibn Khaldun: The Mediterranean in the 14th century : rise and fall of Empires : exhibition in the Real Alcázar of Seville, May-September 2006. Seville: Fundación El Legado Andalusí; Fundación José Manuel Lara.

Shen fuwei (1980). Tangtai duhuan de Molin zhixing [ Travels of the Tang's dynasty Duhuan in Molin]. Shijie Lishi. (6), 48-54.

Shen fuwei (1983). yuantai hanghaijia wangdayuan zhouyou feizhou de lishi yiyi [ The historical significance of the travels of the yuan's dynsaty navigator wangdayuan around Africa]. Xi Ya Fei Zhou. (1).

Shen fuwei (1984a). yuanhuanzhou youyafei de hanghaijia wangdayuan--"haishang sichuzhilu" (liu) [Yuanhua Wang Dayuan, a navigator traveling around Asia and Africa-"Maritime Silk Road" (6). Liaowang. (42), 44-45.

Shen fuwei (1984b). Zhongguo he feizhou guojia zuizao jianli de waijiao guanxi [ The earliest diplomatic relations between china and the African countries]. Haijiao Lishi.

Sherwani, H. K., \& Joshi, P. M. (1974). History of Medieval Deccan, 1295-1724: Mainly cultural aspects. History of Medieval Deccan, 1295-1724. Retrieved from https://books.google.com/books?id=9T5uAAAAMAAJ

Shoko Yamada (2019). History and Development of Education in Africa. In Oxford Research Encyclopedia of Education. https://doi.org/10.1093/acrefore/9780190264093.013.56

Smidt, W. G.C. (2001). A Chinese in the Nubian and Abyssinian Kingdoms (8th Century). Chroniques Yéménites. Advance online publication. https://doi.org/10.4000/cy.33

Snow, P. (1988). The star raft: China's encounter with Africa. Cornell paperbacks. Ithaca N.Y.: Cornell University Press.

Sowa, P. A. (2002). How valuable are student exchange programs? New Directions for Higher Education, 2002(117), 63-70. https://doi.org/10.1002/he.49

Stein, S. K. (Ed.) (2017). The sea in world history: Exploration, travel, and trade. Santa Barbara, California: ABCCLIO.

Stewart, D. J. (2012). The Middle East today: Political, geographical and cultural perspectives (2nd ed.). London: Routledge.

Suood, H. A. (2014). The Maldivian legal system. Male: Maldives Law Institute. 
Suryadinata, L. (2005). Admiral Zheng He \& Southeast Asia. Singapore: International Zheng He Society.

Szczepanski, K. (2008, May 17). The Battle of Talas. ThoughtCo. Retrieved from https://www.thoughtco.com/thebattle-of-talas-195186

Takács, S. A., \& Cline, E. H. (2015). The ancient world (1st, 1-5). London: Routledge.

Tan, K. S. (2014). Dynastic China: An elementary history / Tan Koon San. Kuala Lumpur: The Other Press.

Tan Ta Sen (2005). Did Zheng He Set Out to Colonize Southeast Asia? In Admiral Zheng He and Southeast Asia (pp. 42-57). ISEAS-Yusof Ishak Institute.

Tellis, G. J., \& Rosenzweig, S. (2018). How transformative innovations shaped the rise of nations: From ancient Rome to modern America (1st ed.). London: Anthem Press.

Thierry Meynard (2018). Fan Shouyi, A Bridge Between China And The West Under The Rite Controversy. Annales Missiologici Posnanienses, 22. https://doi.org/10.14746/amp.2017.22.2

Tie, W., \& Li, X. (1994). Zhongguo Musilin chao jin ji shi (Di 1 ban). Yinchuan: Ningxia ren min chu ban she.

Vande Berg, M., Paige, R. M., \& Lou, K. H. (Eds.) (2012). Student learning abroad: What our students are learning, what they're not, and what we can do about it (First edition). Sterling, Virginia: Stylus Publishing, LLC. Retrieved from http://site.ebrary.com/lib/stanford/Doc?id=10619591

Wade, G. (2005). THE ZHENG HE VOYAGES: A REASSESSMENT. Journal of the Malaysian Branch of the Royal Asiatic Society, $78(1$ (288)), 37-58. Retrieved from www.jstor.org/stable/41493537

Waines, D. (2010). The odyssey of Ibn Battuta: Uncommon tales of a medieval adventurer / David Waines. London: I. B. Tauris.

Wang ting (2001). Mo lin: zhongguo zhongshiji guanyu xifei de jizai [ Mo lin: Chinese middle age records about west Africa]. Zhongguo Shi Yanjiu. (1).

Warf, B. (2010). Encyclopedia of geography. Gale virtual reference library. Thousand Oaks, Calif.: Sage Publications.

Wilensky, J. (2002). The Magical Kunlun and "Devil Slaves": Chinese Perceptions of Dark-skinned People and Africa Before 1500. Sino-Platonic papers: Department of Asian and Middle Eastern Studies, University of Pennsylvania. Retrieved from https://books.google.com/books?id=D5hxAAAAMAAJ

Wolfe, M. (1997). One thousand roads to Mecca: Ten centuries of travelers writing about the Muslim pilgrimage. New York: Grove Press.

Wyatt, D. J. (2010). The Blacks of premodern China. Encounters with Asia. Philadelphia: University of Pennsylvania Press.

Xu Yongzhang (1980). wo guo guji zhong guanyu feizhou de jizai [Records about Africa in the Chinese ancient books]. Shijie Lishi. (6), 53-61.

Yamashita, M. S., Guadalupi, G., \& Bibb, E. (2006). Zheng He: Tracing the Epic Voyages of China's Greatest Explorer. Vercelli, Italy: White Star Publishers.

Yuan zhenguo (2019). Jiaoyu gongping de zhongguo moshi [The Chinese Model of Educational Equity]. Zhongguo Jiaoyu Xuekan. (09), 1-5.

Zhang, T. (2002). Chinese Strategic Culture: Traditional and Present Features. Comparative Strategy, 21(2), 7390. https://doi.org/10.1080/01495930290043056

Zhang Wenqin. XIE QINGGAO1 AND PORTUGAL. Retrieved from http://www.icm.gov.mo/rc/viewer/20023/1078

Zhang xing (1977). zhonguo jiaotongshike huibian [Compilation of Chinese and Western Traffic History. Volume Two]. Beijing: Zhonghua shuju.

Zhang ying (2014). Tang tai luxingjia Duhuan youli kaozheng [examining the travels of the Tang's dynasty traveler Du huan]. Lanzhi Shijie. (21), 99-100.

Zhao, Z. J. Common chinese folk sayings. Learn modern simplified Chinese language series. [Place of publication not identified]: China Publishing House Pt.

Zhao rukuo, \& Yang bowen (2000). Zhu fan zhi jiao shi. Zhi fang wai ji jiao shi [ A proofreading of the Description of Barbarian Nations, Records of Foreign People.]. Beijing: Zhonghua shuju.

Zhou, Z., \& Spangler, J. (2018). Cultural and educational exchanges between rival societies: Cooperation and competition in an interdependent world / editors, Chuing Prudence Chou and Jonathan Spangler. Education innovation. Singapore: Springer.

Zhou qu fei (1936). Ling wai Tai Da [Representative Answers from the Region beyond the Mountains]: Shang wu yin shu guan. 